Annales Missiologici Posnanienses t. 20 (2015), s. 71-88

DOI: $10.14746 / \mathrm{amp} .2015 .20 .6$

\author{
MARTA JELONEK, JOANNA GADZIŃSKA, JĘDRZEJ GADZIŃSKI \\ Prywatne Przedszkole „Fistaszki”, Poznań / Private Kindergarten „Fistaszki”, Poznan; \\ Ogród Botaniczny Uniwersytetu im. Adama Mickiewicza w Poznaniu / \\ / Botanical Garden of the Adam Mickiewicz University in Poznan; \\ Uniwersytet im. Adama Mickiewicza w Poznaniu / Adam Mickiewicz University in Poznań
}

\title{
Trąd i jego postrzeganie na przestrzeni dziejów
}

Doktor Wanda Błeńska - nazywana poznańską Matką Trędowatych - przez 43 lata leczyła holistycznie osoby cierpiące na trąd - chorobę znaną od wieków i rozpowszechnioną na całym świecie. W tym kontekście warto zastanowić się nad istotą tego schorzenia oraz spojrzeć całościowo na sytuację osób nią dotkniętych. Trąd (z gr. lepra) od zawsze wzbudzał odrazę i lęk w społeczeństwach, w których się pojawiał. Do dziś w niektórych społecznościach bywa wiązany z karą za grzechy i powodem stygmatyzacji (Brakel, van 195). Dla zarażonych nim osób jest przyczyną niewyobrażalnego cierpienia fizycznego, psychicznego oraz duchowego. Współczesnemu człowiekowi z krajów tzw. „cywilizacji zachodniej” choroba Hansena (jak często określa się trąd) kojarzy się jednak zazwyczaj z przeszłością. Faktycznie, od XX w. wcześnie wykryty trąd jest całkowicie wyleczalny, a z Europy zniknął w zasadzie już wcześniej dzięki poprawie warunków życiowych. Trzeba jednak zauważyć, że choroba ta obecna jest także i dziś na świecie, powodując cierpienie, niepełnosprawność, a czasem nawet i śmierć osób nią dotkniętych. Według danych Światowej Organizacji Zdrowia (WHO) w roku 2012 trąd zdiagnozowano u 232857 osób, co daje niemal 638 przypadków dziennie. W wielu krajach Afryki i Azji trąd jest nadal poważnym zagrożeniem. Oprócz konsekwencji zdrowotnych w dalszym ciągu powoduje tam marginalizację społeczną chorych i ich odrzucenie, nawet przez najbliższych członków rodzin (Molewska i Pawelec 107).

W efekcie problem trądu pozostaje wciąż aktualny. W literaturze poruszającej ten temat dominują prace dotyczące jego medycznych i biologicznych aspektów. W Polsce publikacje z tego zakresu przygotowali m.in. Augustyno- 
wicz-Kopeć i Zwolska, Janaszek, Nowak i Suryło. Dużo materiałów dotyczących praktyki leczenia trądu pozostawiła również np. W. Błeńska (w dalszej części artykułu posłużono się m.in. przygotowanymi przez nią opisami części objawów). Bardzo bogata jest literatura zagraniczna. Liczne prace na temat trądu publikowane były zwłaszcza na łamach czasopism takich jak Leprosy Review, Tropical Medicine \& International Health, New England Journal of Medicine. Pomimo dominującego „podejścia medycznego” niektóre źródła zwracają również uwagę na aspekty społeczne związane m.in. z podejściem lokalnych społeczności do osób chorych na trąd (głównie artykuły w Leprosy Review). Również prace teologiczne i historyczne podejmują ten temat (m.in. polscy paleopatolodzy - Dzierżykray-Rogalski, Gładykowska-Rzeczycka). Wydaje się jednak, że w polskiej literaturze brakuje wciąż całościowego ujęcia problematyki trądu z uwzględnieniem wszystkich jej aspektów.

Autorzy artykułu podejmują próbę przyjrzenia się tematowi trądu pod różnymi kątami. Krótko zarysowane aspekty medyczne tej choroby stanowią punkt wyjścia do rozważań na temat miejsca tej choroby w historii ludzkości. Przyjrzano się przede wszystkim tematyce trądu i chorych na trąd, która pojawia się na kartach Biblii, zarówno w Starym, jak i Nowym Testamencie. Nieco miejsca poświęcono również sytuacji osób dotkniętych tą chorobą na przestrzeni dziejów, a także współczesnym problemom związanym z występowaniem trądu. Na koniec przywołano również kilka przykładów zaangażowania osób duchownych i świeckich w niesienie pomocy chorym.

Podkreślić należy, że artykuł nie wyczerpuje w całości poruszanej problematyki. Autorzy nie wnikają dogłębnie w poszczególne kwestie. Podejmują za to próbę całościowego ujęcia tematyki związanej z chorobą Hansena i zwracają uwagę na różnorodność aspektów i problemów, które łączyć można z historią występowania trądu na świecie.

\section{Trąd - aspekty medyczne}

Pionierskie wyniki badań nad trądem przedstawił w 1873 r. norweski uczony Armauer Hansen, odkrywając Mycobacterium leprae (bakterię wywołującą trąd) nazywaną później potocznie prątkiem Hansena (Augustynowicz-Kopeć i Zwolska). Trąd jest zakaźną, wyleczalną chorobą przewlekłą. Mapa jej występowania $\mathrm{w}$ dużej mierze pokrywa się z mapą ubóstwa na świecie. Dotyka głównie osób z obniżonym poziomem odporności komórkowej spowodowanym m.in. niedożywieniem organizmu. Źródłem zakażenia jest bezpośredni kontakt z chorymi, a prątek Hansena przenoszony jest przede wszystkim drogą kropelkową. Faza ukryta choroby jest wyjątkowo długa - okres inkubacji może trwać 5 lat, a ujawnienia nawet 30. Trąd atakuje skórę i nerwy położone 
bezpośrednio pod nią, głównie nerwy twarzy oraz kończyn (Augustynowicz-Kopeć i Zwolska).

Immunologiczna odpowiedź organizmu na kontakt z prątkiem, jak również częściowo uwarunkowania genetyczne sprawiają, że u chorych mogą wystąpić różne postacie trądu, w tym: dwie biegunowe odmiany kliniczne - T (tuberkuloidowa) lub L (lepromatyczna) albo jedna z postaci B (od ang. borderline granica), czyli granicznych. Łagodniejsza postać biegunowa to tzw. trąd tuberkuloidowy (tuberkuliczny), określany także gruźlicopodobnym. Oznaczany jest on jako Pauci Bacillary (PB), czyli małobakteryjny i dzięki temu niezakaźny. Na skórze pojawiają się nacieki komórkowe oraz 1-3 niesymetrycznie ułożonych plam. Ich płaszczyzna jest zazwyczaj sucha, pozbawiona włosów, a także czucia, gdyż dochodzi do obrzęku nerwów powierzchniowych. Uszkodzenia nerwów pojawiają się wcześnie, intensywnie degenerują aksony oraz powodują powstawianie zimnych ropni. W konsekwencji chorzy m.in. przestają odczuwać temperaturę i ból (przyczyna częstych oparzeń i innych wypadków), pojawiają się odleżyny, paraliż mięśni stóp, rąk, twarzy, przykurcze, a ostatecznie martwica tkanki, co prowadzi do utraty części ciała - głównie palców kończyn górnych i dolnych (Augustynowicz-Kopeć i Zwolska; Janaszek 578).

Druga postać biegunowa - lepromatyczna - jest wielobakteryjna (MB Multi Bacillary) i zaraźliwa. Określa się ją mianem guzowatej - u chorego w tkance podskórnej i skórze występują guzy. Niekiedy tworzą one trędowaty rumień guzowaty (przy czym wykwit guzków jest bardzo bolesny), wraz z którym często pojawia się białkomocz, zapalenia jąder i inne zaburzenia natury ogólnej (Emond, Rowland i Welsby 138). Objawami są także twarde obrzęki, które mogą powodować trwałe zniekształcenia. Trąd atakuje generalnie całą skórę, układ siateczkowo-śródbłonkowy, nerwy obwodowe, stawy, jądra, oczy, śluzówki ust i nosa, czyli głównie tzw. miejsca „chłodne”, unikając równocześnie lokalizacji w ciepłych miejscach, jak pachy i pachwiny. W trądzie lepromatycznym zmiany skórne są drobne, ale liczne - ułożone symetrycznie (w przeciwieństwie do zmian skórnych $\mathrm{w}$ trądzie T). Charakterystyczną cechą jest tzw. „lwia twarz”. Skóra marszczy się, grubieje, znacznie poszerza się nos i płatki uszu chorego. Dobrze leczony trąd powoduje jednak cofnięcie się tych objawów i twarz może w dużej mierze odzyskać poprzedni wygląd (Emond, Rowland i Welsby 138).

$\mathrm{W}$ trądzie występuje także szereg postaci B-granicznych, zwanych również „mieszanymi”. Mogą one przesunąć się w kilku kierunkach: BT, BB lub BL. BT charakteryzuje się naciekami podobnymi jak w trądzie T, ale ich liczba musi być większa niż trzy. Jest to postać skąpobakteryjna (PB), niezakaźna, lecz dochodzi w niej do największych i bardzo bolesnych uszkodzeń nerwów obwodowych. Postać BL jest bogatobakteryjna (MB) i zakaźna. Widoczne zmiany skórne przypominają często zmiany w trądzie L (począwszy od płat- 
ków usznych i nosa). Zaburzenia czucia są w tym przypadku niewielkie. Najmniej stabilną grupą jest BB. Dobrze rozpoznana i leczona może ochronić chorego od uszkodzenia nerwów i rozwinięcia się trądu BL lub L. Mimo że wyniki badań laboratoryjnych często są ujemne, to i ten rodzaj zaliczany jest do zakaźnych. Występują w nim nacieki pierścieniowate z nieuszkodzoną skórą wewnątrz, pośrodku. Ostatnim, najbardziej zagadkowym typem mieszanym jest typ I (od ang. Indeterminate - nieokreślony). Jest to stadium początkowe trądu, który przechodzi w postaci wielobakteryjne (L, BL, BB) lub małobakteryjne (T, BT) albo podlega samowyleczeniu. Jest on najczęściej spotykany u dzieci i rozpoznawany na podstawie pojedynczych plam, bez powiększenia nerwów, zaburzeń czucia i obecności prątków Hansena (Kocięcka).

Cechą charakterystyczną większości odmian trądu są uszkodzenia nerwów obwodowych. Chorzy mogą doświadczyć m.in. problemów z nerwem twarzowym - opadania kąta ust, niedomykania powiek (prowadzącego do uszkodzenia rogówki) - oraz z nerwem trójdzielnym - np. w postaci znieczulenia gałki ocznej i zaprzestania mrugania. Nierzadko dodatkową chorobą oczu u tych pacjentów jest jeszcze jaglica, która nieleczona: „,...] prowadzi do deformacji powiek, zmętnienia rogówki i ostatecznie - ślepoty" (Nowak, za: Nawrocka 31). Zmiany zachodzić mogą również w kończynie dolnej i górnej (i dotyczyć nerwów podkolanowych, piszczelowych). Skutkiem, jak podaje Błeńska (5), mogą być „owrzodzone i zniekształcone stopy, nekroza kości”, „koguci chód”, a w dalszej kolejności również brak możliwości samodzielnego poruszania (przy braku odpowiedniego leczenia, zaopatrzenia ortopedycznego i opieki może to doprowadzić do wycieńczenia organizmu i śmierci głodowej).

W kończynie górnej najczęściej atakowane są trzy nerwy: łokciowy, pośredni i promienisty. Jak opisuje Błeńska (6), w efekcie pacjenci nie mogą „utrzymać w ręku kartki papieru między 4 i 5 palcem”, nie mają „wyczucia siły uchwytu i uderzenia”, nie mogą „sprawnie jeść palcami, zapinać guzików, przybliżyć kciuka do małego palca". W efekcie dochodzi do znieczulenia całej ręki, atrofii mięśni i szponowatości (tzw. małpia ręka). Ręce szybko się męczą, brak im zręczności, są znieczulone, nie mają wyczucia siły uderzenia, chwytu itd. Uszkodzenie ostatniego z wymienionych nerwów może nawet wywołać „opadnięcie ręki, która staje się bezsilna”.

Podczas przebiegu choroby Hansena poza etapami względnie spokojnymi występują również okresy (zwane reakcjami), które są wyjątkowo ostre. Reakcje trądowe są bardzo bolesne dla chorych i prowadzą do zniekształceń ciała. Ich nasilenie, objawy i przebieg różnią się w zależności od postaci trądu. Najboleśniejsze reakcje przechodzą pacjenci chorujący na odmianę BL. Doświadczają oni stanów zapalnych wielu nerwów równocześnie i stazy, czyli bardzo bolesnych obrzęków nóg i rąk. Jako przyczyny wystąpienia reakcji najczęściej wskazuje się zakażenie wirusowe i szczepienie, doustnie podawa- 
ny jod, zmiany hormonalne, ale także wyjątkowo silny stres - fizyczny i psychiczny (Kocięcka).

Warto w tym miejscu przyjrzeć się także mikrobowi, który odpowiada za trąd. Mycobacterium leprae jest bakterią kwasooporną, blisko spokrewnioną z prątkiem gruźlicy, jednakże namnaża się ona wyjątkowo wolno. Zdaniem B. Stryjewskiej z Narodowego Ośrodka Leczenia Trądu w Baton Rouge (USA), spośród wszystkich patogenów ludzkich namnaża się najwolniej i potrzeba aż dwóch tygodni, by bakteria się podzieliła (Sermak). Tłumaczy to wyjątkowo długi czas wylęgania się choroby i jej objawów. Prątek jest zdolny przeżyć poza organizmem żywym (w wilgotnym środowisku) 8-12 dni (Kocięcka). Ponieważ hodowla $M$. leprae nie jest możliwa in vitro, przełomowym momentem w badaniu trądu było odkrycie Sheparda z 1960 r., któremu udało się namnożyć bakterie u myszy (Kocięcka 57). Wkrótce odkryto także podatność pancernika na zarażenie prątkami Hansena. Dzięki temu możliwe stało się rozszerzenie zakresu badań nad genomem $M$. leprae, co poskutkowało rozpoczęciem prac nad szczepionką przeciw trądowi. Ocenia się, że razem z wymienionymi zjawiskami immunologicznymi wpływ na zachorowanie na trąd mają także czynniki genetyczne oraz zagęszczenie populacji, okres ekspozycji prątków Hansena oraz ewentualny kontakt z innymi bakteriami z gatunku Mycobacterium.

Do zakażenia $M$. leprae może dojść poprzez bezpośredni, długotrwały kontakt z samą osobą chorą. Prątek Hansena wydostaje się z zarażonego organizmu przede wszystkim górnymi drogami oddechowymi poprzez wydzieliny z jamy nosowej (drogą kropelkową) oraz poprzez skórę z wydzielinami z owrzodzeń. Innym źródłem zakażenia są łzy, ślina, przenikanie prątków poprzez łożysko matki do pępowiny dziecka, a także w pokarmie chorej matki (Kocięcka). Zachowanie podstawowych zasad higieny, w tym przede wszystkim regularne mycie rąk po każdorazowym kontakcie z chorym, wystarczy, by uchronić się od bakterii.

Dzięki prowadzonym w przeszłości badaniom obecnie leczenie trądu nie jest ani trudne, ani bardzo kosztowne. Ocenia się, że koszt leczenia jednej osoby (aż do całkowitego wyleczenia) wynosi jedynie niecałe 100 dolarów (Ferenc 234). Od 1981 r. w wyniku działań Światowej Organizacji Zdrowia (WHO) wprowadzono nowoczesną terapię wielolekową - tzw. MDT (ang. Multi-Drug Therapy), która do dziś jest najpowszechniejszym sposobem leczenia trądu. Jest ona także zdecydowanie mniej czasochłonna niż wcześniej stosowane metody, które polegały na podawaniu kombinacji kilku leków (farmakoterapię trzeba było jednakże kontynuować przez wiele lat). Pacjentów z trądem MB leczy się rifampicyną, klofazyminą i dapsonem przez okres 24 miesięcy z możliwością skrócenia do 12 miesięcy. Z kolei w terapii dla chorych z trądem PB stosuje się jedynie dapson z rifampicyną (przez okres 6 mie- 
sięcy). Od 1995 r. MTD została bezpłatnie udostępniona krajom, w których trąd występuje endemicznie. Kilka lat później wprowadzono także specjalną jednorazową dawkę leków (tzw. ROM - od rifampicyny, ofloksacyny, minocykliny) dla osób, u których wykryto pojedynczą plamę trądową (Błeńska 7).

W przypadku rozważań nad leczeniem trądu nie należy zapominać również o konieczności leczenia jego skutków (Molewska i Pawelec 107, 116). Przykurcze, zaburzenia czucia, opadające kończyny są konsekwencjami późnej diagnozy i zbyt późno podjętego leczenia. Ze względu na słaby dostęp do opieki medycznej w wielu krajach tzw. Trzeciego Świata upływają miesiące, a nawet lata, zanim choroba zostanie zdiagnozowana (i potwierdzona badaniem laboratoryjnym). W efekcie dochodzi do spustoszenia organizmu i nieodwracalnych zmian fizycznych (takie trwałe następstwa trądu nie są w zasadzie wyleczalne). Nadal zdarza się, że nieleczona choroba Hansena prowadzi do śmierci.

\section{Trąd w Starym Testamencie}

Do czasu dokładnego poznania i opisania trądu oraz wprowadzenia nowoczesnych metod jego leczenia przez wiele wieków budził on strach i odrazę. Ocenia się, że jest on jedną z najstarszych chorób znanych w świecie. Trudno jednak jednoznacznie określić miejsce i czas jego pochodzenia, choć niektórzy naukowcy wskazują, że najwcześniejsze wzmianki o trądzie pojawiają się na Bliskim Wschodzie, w Chinach i Indiach (Trautman 691; Augustynowicz-Kopeć i Zwolska).

Długa historia choroby znalazła odzwierciedlenie w wielu zapisach historycznych, w tym także wielokrotnie pojawiała się na kartach Pisma Świętego. Jednych z pierwszych pisemnych informacji o trądzie dostarczają nam księgi Starego Testamentu. W 13 i 14 rozdziale Księgi Kapłańskiej (Kpł 13-14) redagowanej na początku $\mathrm{V}$ w. p.n.e. znajduje się m.in. dokładny opis chorób skóry nazwanych ogólnie trądem. Wśród licznych praw przywołanych w Księdze znalazło się „Prawo czystości” (Kpł 11-14), które zawiera m.in. „Przepisy dotyczące trądu”. Przykładowo w rozdziale 13 autor szczegółowo objaśnia sposób postępowania w przypadku pojawienia się na skórze białej plamy. Zauważa przy tym, że nie każda taka plama musi być zmianą trądową. Decydujący głos w tej kwestii powinien należeć do kapłana, który odpowiadał za czystość rytualną. Jak podaje Matwiejczuk, powszechne w tym czasie było stosowanie siedmiodniowych kwarantann w celu uzyskania pewności osądu. Nie podejmowano więc decyzji pochopnie, a przy tym chorego wykluczano ze wspólnoty tylko na czas trwania jego choroby.

W dalszych podrozdziałach Księgi Kapłańskiej przedstawione zostały również konkretne objawy trądu. Zaliczono do nich otwarte ropiejące rany 
wrzodowe, obrzmiałe, powiększone nerwy, wklęśnięcia w skórze (mogą oznaczać miejsca, które ,zgniły”). Wyraźnie można też zauważyć, że autor w tym kontekście wymienia różne schorzenia, takie jak grzybica, pokrzywka, łysienie, a także ,trąd na przedmiotach takich jak tkaniny i skóry”, czyli przypuszczalnie pleśni (,,To jest prawo odnoszące się do wszelkiej plagi trądu i grzybicy, trądu ubrania i domu, nabrzmienia, wysypki i białej plamy, aby pouczyć, kiedy coś jest czyste, a kiedy nieczyste. To jest prawo odnoszące się do trądu" [Kpł 14,54-57]).

W omawianym fragmencie Starego Testamentu w odniesieniu do osoby chorej na trąd pojawia się określenie „nieczysty”. Każda taka osoba musiała zostać odsunięta od wspólnoty i odizolowana od miejsc publicznych: „Trędowaty, dotknięty tą plagą, będzie miał rozerwane szaty, włosy nie uczesane, brodę zasłoniętą i będzie wołać: Nieczysty, nieczysty! Przez cały czas trwania tej choroby będzie nieczysty. Będzie mieszkał w odosobnieniu. Jego mieszkanie będzie poza obozem" (Kpł 13, 45-46). Izolacja chorych wywoływana powszechnym lękiem przed zakażeniem stała się podstawową metodą ograniczającą rozprzestrzenianie się trądu. Przyczyniła się jednak również do skazywania osób nim dotkniętych na całkowitą samotność i izolację.

Starotestamentalne znaczenie trądu wprowadza jeszcze jeden wymiar patrzenia na chorobę Hansena - jako karę za grzechy. Jest to motyw, który będzie aktualny również w kolejnych epokach. W Księdze Liczb (Lb) czytamy historię Miriam - siostry Mojżesza, która szemrała przeciwko swojemu bratu razem z Aaronem na pustyni: „Oto Miriam stała się nagle biała jak śnieg od trądu. Gdy Aaron się do niej zwrócił, spostrzegł, że była trędowata. Wtedy rzekł Aaron do Mojżesza: Proszę, panie mój, nie karz nas za grzech, któregośmy się nierozważnie dopuścili i jesteśmy winni. Nie dopuść, by ona stała się jak martwy [płód], który na pół zgniły wychodzi z łona swej matki” (Lb 12,9-12).

Analogiczną rolę odgrywa trąd w opowieści o Naamanie, przywódcy wojsk Arama, która znalazła się w Drugiej Księdze Królewskiej. Po zwycięskiej bitwie chorujący na trąd Naaman wybrał się do Izraela do proroka Elizeusza, prosząc o uzdrowienie, które też otrzymał. Prorok nie chciał zapłaty, uzdrowienie przypisując nie sobie, lecz Bogu. Wykorzystać to postanowił jednak jego sługa Gechazi. Kierując się chciwością, wyruszył za Aramejczykiem i podczas spotkania prosił o dary za uleczenie. Jednak po ich odebraniu szybko spotkała go kara za nieuczciwość. Po słowach Elizeusza: „A trąd Naamana przylgnie do ciebie i do twojego potomstwa na zawsze" (2 Krl 5,27a), Gechazi „oddalił się od niego biały jak śnieg od trądu” (2 Krl 5,27b).

Podobne zapisy znaleźć można również w Księdze Kronik. Dla króla Ozjasza znamię trądu na czole stało się karą za jego gniew i pychę (2 Krn 26,1-23).

Przekonanie, że trąd jest formą kary za grzechy, było, obok możliwości zakażenia, drugim powodem izolacji trędowatych. Jak podaje Andrzejak (31), 
ówcześni rabini wśród grzechów, za które mógł zostać zesłany na człowieka trąd, wymieniali: pychę, oszczerstwa, nieczystość w kontaktach cielesnych. W efekcie powszechne było przekonanie, że chorzy zasłużyli na swe cierpienia. Można przypuszczać, że takie podejście zaważyło na skrajnie negatywnym postrzeganiu osób dotkniętych trądem na długie wieki.

\section{Trąd w Nowym Testamencie}

Diametralnie inną perspektywę odsłaniają nam o kilka wieków młodsze teksty Nowego Testamentu. Jezus prezentuje zupełnie odmienne podejście do chorego niż reszta społeczeństwa kultywująca utrwalone przez wieki sposoby postępowania (izolację i pogardę). Ewangelie ukazują, że nie stroni On od spotkań z cierpiącymi, słabymi, ubogimi. W efekcie styka się również z osobami chorymi na trąd („nieczystymi”), które słysząc o czynionych przez Jezusa cudach, łamią zakaz zbliżania się do ludzi zdrowych i przychodzą do Niego: „A oto zbliżył się trędowaty, upadł przed Nim i prosił Go: Panie, jeśli chcesz, możesz mnie oczyścić. Jezus wyciągnął rękę, dotknął go i rzekł: Chcę, bądź oczyszczony! I natychmiast został oczyszczony z trądu" (Mt 8,2-3 - por. Mk 1,40-45).

Wydaje się, że Jezus, dotykając części ciała dotkniętych chorobą, oprócz uzdrawiania przełamywał również lęk uczniów przed osobami trędowatymi. Podchodząc do trędowatych z miłością, przywracał im jednocześnie godność (Łk 5,12a.13b). Jadając z nimi (por. Mk 14,3), pokazywał, że należy im się uwaga i szacunek.

Jak notuje św. Łukasz, uzdrowień z trądu musiało być wiele ( Łk 7,22). Ewangelie nie podają jednak dokładnych liczb. Podczas jednego ze spotkań dzięki interwencji Jezusa dochodzi do oczyszczenia 10 osób:

Gdy wchodził do pewnej wsi, wyszło naprzeciw Niego dziesięciu trędowatych. Zatrzymali się z daleka i głośno zawołali: Jezusie, Mistrzu, ulituj się nad nami! $\mathrm{Na}$ ten widok rzekł do nich: Idźcie, pokażcie się kapłanom! A gdy szli, zostali oczyszczeni. Wtedy jeden z nich, widząc, że jest uzdrowiony, wrócił chwaląc Boga donośnym głosem, padł na twarz u Jego nóg i dziękował Mu. A był to Samarytanin (Łk 17,12-16).

Jezus uzdrawiał sam, ale i przykazał swoim uczniom, aby i oni, mocą Ducha Świętego, pomagali potrzebującym. Wzywał ich: „Uzdrawiajcie chorych, wskrzeszajcie umarłych, oczyszczajcie trędowatych, wypędzajcie złe duchy" (Mt 10,8a). Zadanie to podjęli nie tylko uczniowie za czasów Jezusa, ale wzorowały się na Nim (i nadal wzorują) kolejne pokolenia. 


\section{Sytuacja osób chorych na trąd na przestrzeni wieków}

Jak zauważa Szałata (13), trąd rozprzestrzeniał się w starożytności w dużej mierze jako efekt ekspansji Imperium Rzymskiego i przemieszczania się wojsk (por. Trautman 692). W rezultacie szybko stał się znany w całym starożytnym świecie. Już w IV w. zaczęto budować osady mieszkalne dla trędowatych zwane leprozoriami (od łac. Leprosus - trędowaty). Chorych izolowano, by ograniczyć rozprzestrzenianie choroby, która wzbudzała ogromny lęk w społeczeństwach wywoływany strasznymi jej skutkami i brakiem możliwości wyleczenia (Browne 17). Jak zauważa Łęczycka (22):

To oddzielenie chroniło zdrowych, ale dla chorych miało wyłącznie negatywne skutki. Pozostawali oni w nieludzkich warunkach, bez pomocy i z pełną świadomością swego losu. Ci, u których pojawiły się pierwsze objawy, trafiali do leprozoriów, by nigdy z nich nie wrócić; skazani na powolne konanie ciała i jeszcze powolniejsze duszy sami dla siebie nawzajem stawali się wsparciem, jeśli siły im na to pozwalały.

Największy rozwój leprozoriów przypadł na okres średniowiecza. W Europie w XIII w. istniało ich około 19 tysięcy (Supady 80). Przyczyną szybkiej ekspansji choroby były w dużej mierze migracje. Miały na nie wpływ licznie prowadzone w tym okresie wojny, w tym przede wszystkim wyprawy krzyżowe. Bardzo często towarzyszyły im także epidemie i zarazy, które osłabiały odporność żołnierzy, dzięki czemu łatwiej zapadali oni na trąd (Supady 80).

$\mathrm{Z}$ okresem wypraw krzyżowych wiązać należy również początki posługi wśród osób trędowatych. W XI w. podczas pierwszej z takich wypraw zapoczątkował swoją działalność Zakon Rycerzy św. Łazarza (Szałata). Nazwa ta nawiązuje do biblijnych historii związanych z postacią Łazarza. W pierwszej z nich żebrak pokryty wrzodami nie doświadcza pomocy ze strony bogacza i umiera w samotności (por. Łk 16,19-31). Drugi Łazarz - brat Marii i Marty po kilku dniach od śmierci zostaje wskrzeszony przez Jezusa (por. J 11,1-44). Wybór patrona zakonu dobrze podkreśla to, że w średniowieczu chorych uważano w zasadzie za „umarłych za życia”. W intencji osoby, u której wykryto trąd, niemal od razu odprawiano Mszę św. z liturgią za zmarłych. Szczegółowo przyjęty ceremoniał opisuje Matwiejczuk:

Wygnaniu chorego towarzyszył religijny rytuał, który możemy zrekonstruować według sakramentarzy (agend liturgicznych). Rozpoczynał się mszą za zmarłych w intencji chorego. Po jej zakończeniu kapłan i wierni wychodzili w procesji na przykościelny cmentarz. Tam ksiądz wprowadzał trędowatego do świeżo wykopanego grobu i posypywał mu głowę ziemią. Od tej pory człowiek ten był już 
symbolicznie martwy. Ksiądz dawał mu „odzież ochronną”, która miała chronić zdrowych przed zarażeniem: rękawice, zasłonę na twarz, parę butów, kapelusz i płaszcz. [...] Najważniejszym atrybutem trędowatego była kołatka.

Kołatka lub dzwonek oraz głośne wołanie „nieczysty, nieczysty” miały ostrzegać zdrowe osoby o niebezpieczeństwie spotkania ze zbliżającym się trędowatym (Trautman 690). Zestaw zasad obowiązujących chorego był jednak znacznie dłuższy. Koniecznością było noszenie jaskrawych szat z naszytą literą „L”. Zakazane były kąpiele, picie wody ze źródeł oraz spożywanie posiłków w towarzystwie ludzi zdrowych. Z kolei rozmowa z osobą niezakażoną możliwa była jedynie w sytuacji, gdy trędowaty ustawiony był pod wiatr (Ferenc 230-231). Podobne zasady obowiązywały prawdopodobnie już od starożytności, choć trudno jednoznacznie określić czas ich wprowadzenia.

Trąd niósł ze sobą również znaczące konsekwencje dla życia rodzinnego. W przypadku choroby jednego z małżonków udzielano automatycznie unieważnienia małżeństwa, a osoba zdrowa uznawana była za owdowiałą. Praktyka ta obowiązywała aż do XII-XIII w., kiedy to papieże Aleksander III i Grzegorz IX za pomocą odpowiednich zarządzeń ostatecznie powstrzymali takie praktyki (Matwiejczuk).

W średniowieczu zakażenie trądem wiązano bardzo często ze starotestamentową karą za grzechy. Dotykała ona zarówno biednych, jak i bogatych. Jednym z najbardziej znanych trędowatych z tego okresu był jerozolimski król Baldwin IV (panował w XII wieku). Młody władca, który był ceniony z powodu swojej mądrości i umiłowania pokoju, ukrywał zniekształconą przez trąd twarz za srebrną maską (Szałata 13). Po latach stał się on postacią legendarną - romantycznym bohaterem książek m.in. powieści Zofii Kossak-Szczuckiej Król trędowaty, a ostatnio również kultury masowej i filmu pt. Królestwo Niebieskie (or. Kingdom of Haeven) w reżyserii Ridleya Scotta. Większość trędowatych została jednak bezimienna i umarła w zapomnieniu oraz samotności.

Zakończenie plagi trądu w Europie wiązać należy z pojawieniem się innej śmiercionośnej choroby - dżumy. Tak zwana czarna śmierć, czyli epidemia, która przeszła przez kontynent w XIV w., sprawiła, że życie straciła prawie jedna trzecia ludności Europy. Trędowaci ze swoją obniżoną odpornością nie mieli dużych szans na pokonanie nowej choroby. W efekcie prawie wszyscy zginęli. Trąd wrócił po latach do Europy, ale już nigdy nie stał się aż takim problemem, jak w średniowieczu (por. Trautman 693). 


\section{Dzielo pomocy chorym na trąd}

Mimo powszechnego ostracyzmu, z jakim spotykały się osoby chore na trąd, w ciągu wieków znalazło się wiele osób, które postanowiły podjąć trud pracy z nimi. Wspomniani już lazarianie z Zakonu Rycerzy i Szpitalników św. Łazarza z Jerozolimy opiekowali się trędowatymi głównie poprzez udzielanie wsparcia medycznego. W pewnym wymiarze dołączyli do tej misji również joannici, szpitalnicy - rycerze św. Jana Jerozolimskiego. Działali oni także na terenie Polski, zostawiając trwałe ślady ${ }^{1}$.

Mimo że dzieło budowy szpitali i podejmowanie opieki nad trędowatymi łączyć należy przede wszystkim z rycerzami zakonnymi oraz osobami duchownymi, zadania tego czasami podejmowali się m.in. także członkowie rodzin królewskich. Warto w tym miejscu wspomnieć św. Kingę (ze Starego Sącza), córkę króla węgierskiego Beli IV i żonę Bolesława Wstydliwego. W XIII w. odwiedzała ona przytułki m.in. w Sandomierzu i Krakowie, w tym również domy dla trędowatych. Zapamiętana została jako księżna, która nie przejmując się opiniami dworu i podwładnych oraz nie zważając na swoje królewskie pochodzenie, służyła ubogim i cierpiącym. Jak podaje Wojtczak (137) w życiorysie św. Kingi: „Pokornie i z miłością posługiwała trędowatym, a nawiedzając z pobożności ich domy, oczyszczała ich ropiejące rany, ocierała swą suknią posokę, przewiązywała ich rany, a dając im na koniec powodowana chrześcijańskim uczuciem jałmużnę i ucałowawszy z pokorą ich nogi i rany odchodziła".

Co ciekawe również jej krewne - św. Elżbieta Magdeburska oraz św. Agnieszka Czeska - niosły pomoc trędowatym. Elżbieta założyła dla nich szpital w Magdeburgu, a Agnieszka m.in. szyła oraz naprawiała im szaty (Krzyżostaniak 51-52).

Wzorem dla przywołanych wyżej postaci świętych był żyjący również w tym okresie włoski zakonnik - znany obecnie jako św. Franciszek z Asyżu (por. Krzyżostaniak). Po rezygnacji z bogactw i przywilejów (a pochodził z zamożnej rodziny kupieckiej) oddał się pomocy ubogim i potrzebującym. Poświęcił się naśladowaniu Jezusa w duchu ówczesnej pobożności imitatio Christi, podejmując służbę odtrąconym, w tym także trędowatym, co w interesujący sposób przytacza arcybiskup S. Gądecki w swej homilii (wygłoszonej 12.02.2012):

Dobrze znamy epizod z życia młodego Franciszka z Asyżu, który spośród wszystkich potworności świata najbardziej brzydził się trędowatymi, aż pewnego dnia, jadąc konno w pobliżu Asyżu, zobaczył na wprost siebie trędowatego. Chociaż od-

1 W Poznaniu nadal pomagają joannici - kawalerowie maltańscy oraz istnieje dzielnica zwana - od lazarytów - Łazarzem, a na poznańskiej Wildzie (dawnym terenie wsi Świętego Łazarza) do dziś mieści się budynek, w którym rycerze ci prowadzili leprozorium. 
czuwał wobec niego w najwyższym stopniu wstręt i obrzydzenie, to jednak [...] zsiadł z konia i pocałował go. Po kilku dniach udał się do mieszkań ludzi trędowatych, wręczył każdemu pieniądze, i pocałował ich w rękę i usta. W ten sposób to, co gorzkie, przyjął, jako słodkie.

O tym, jak na przestrzeni dziejów wyglądała sytuacja osób trędowatych nie tylko w Europie, ale i na całym świecie, możemy dowiedzieć się po trosze z zapisków prowadzonych przez misjonarzy. Ocalałe osobiste dzienniki czy korespondencje odsłaniają prawdę o realiach życia w koloniach chorych. W tym miejscu należy wymienić choć kilku wybitnych misjonarzy, którzy podjęli służbę wśród osób dotkniętych trądem.

Prekursorami zorganizowanej i kompleksowej opieki nad trędowatymi w 2 połowie XIX w. byli równolegle na wyspie Molokai na Hawajach bł. Damian de Vuster (belgijski misjonarz Serca Jezusowego) oraz na Madagaskarze polski jezuita bł. Jan Beyzym. Obaj na stałe zamieszkali wśród trędowatych, dzięki czemu zaczęli zmieniać postrzeganie trądu w lokalnych społecznościach. Wprowadzili również ówcześnie wiele innowacyjnych zmian w metodach opieki nad trędowatymi. Błogosławiony Jan wybudował nowoczesny szpital w Maranie dla chorych. Niezwykle istotne dla cierpiących na trąd było również wsparcie duchowe oraz akceptacja ich przypadłości ze strony misjonarzy. Muth-Oelschner (56) przytacza słowa bł. Damiana de Vustera, które dobrze obrazują jego podejście: „Ośmielam się powiedzieć, za apostołem Pawłem, że dla trędowatych stałem się trędowaty, aby ich pozyskać dla Chrystusa. Kiedy więc mówię kazania, posługuję się formą: «my trędowaci»".

Obaj przywołani zakonnicy zakończyli swe życie wśród chorych. Błogosławiony Damian sam umarł na trąd po 16 latach pracy, a bł. Jan z niedożywienia i wyczerpania sił. Ich posługa stała się jednak w latach późniejszych inspiracją dla licznych misjonarzy duchownych i świeckich. Wielu z nich pozostaje bezimiennych, część jednak zyskała szerokie uznanie dzięki działaniom podjętym na rzecz walki z trądem. Jedną z najbardziej znanych na świecie osób, które poświęciły się walce $\mathrm{z}$ tą chorobą, jest bez wątpienia bł. Matka Teresa z Kalkuty. Założyła ona Zgromadzenie Sióstr Misjonarek Miłości, który zajmuje się w dużej mierze pomocą osobom dotkniętym trądem (na temat posługi bł. Matki Teresy powstało wiele opracowań - m.in. biografia autorstwa Kathryn Spink).

Wśród postaci, które zasłużyły się w niesieniu pomocy trędowatym, wspomnieć można wielu polskich misjonarzy. Pracujący w XX w. w Indiach o. Adam Wiśniewski (pallotyn) razem z s. Barbarą Birczyńską założył w stanie Chhattisgarh działający do dziś Ośrodek Rehabilitacji Trędowatych Jeevodaya. Dzieło to kontynuuje obecnie świecka lekarka dr Helena Pyz (informacje o działalności tej placówki można odnaleźć na stronie internetowej 
http://www.jeevodaya.org). Z kolei o. Marian Żelazek (werbista) w Purii (stan Orissa w Indiach) wybudował funkcjonujący do dziś ośrodek dla trędowatych, a także szkołę dla ich dzieci, szpital, przychodnię zdrowia i wiele warsztatów pracy. Nie można też nie wspomnieć o dr Wandzie Błeńskiej, która przez 43 lata posługiwała chorym na trąd w Ugandzie. Dzięki jej staraniom otwarto również nowy szpital w Bulubie oraz powołano do życia ośrodek szkoleniowy mający na celu poszerzanie wiedzy związanej z leczeniem trądu.

\section{Trąd obecnie}

Dzięki rozwojowi medycyny oraz zaangażowaniu wielu osób w walce z trądem w XXI w. choroba ta została znacząco ograniczona. Obecnie zagrożenie trądem nie jest już w zasadzie problemem społeczności krajów europejskich. Ze względu na stosunkowo wysokie standardy higieniczne oraz dobry poziom dostępu do usług medycznych choroba ta praktycznie zniknęła z tej części świata. Wprawdzie, jak podaje Doboszańska (w wywiadzie udzielonym tygodnikowi Idziemy), w Rumunii istnieje jeszcze ostatnie leprozorium w Europie, jednakże liczba pacjentów jest tam znikoma. Jednocześnie trąd pozostaje istotnym problemem w niektórych regionach na świecie (szczególnie na obszarach, gdzie występuje endemicznie - w strefie tropikalnej i subtropikalnej).

Dane zbierane rokrocznie przez WHO (pozyskane ze 115 krajów i terytoriów zależnych) i opublikowane w 2013 r. w ramach serii Weekly Epidemiological Record potwierdzają ten fakt. Wprawdzie w ostatnich latach mamy do czynienia ze spadkiem liczby zachorowań (w okresie 2005-2012 wyniósł on ponad 22\%), to jednak statystyki cały czas są wysokie. W 2012 r. odnotowano prawie 233 tys. nowych przypadków, co daje cztery takie zdarzenia na każde 100 tys. ludności. Jednocześnie należy pamiętać, że dokładna liczba zachorowań może być znacznie wyższa ze względu na fakt, że jedynie część osób zgłasza się do placówek medycznych i ośrodków misyjnych, a niektóre kraje nie udostępniają swoich statystyk. Według szacunków WHO całkowita liczba chorych może wynosić nawet ok. trzy miliony.

Największe zagrożenia związane $\mathrm{z}$ występowaniem i rozprzestrzenianiem się trądu charakterystyczne są dla krajów rozwijających się, które cechuje duże rozwarstwienie społeczne (ryc. 1). W efekcie najwięcej zachorowań notuje się w Azji Południowo-Wschodniej - zwłaszcza w Indiach, Indonezji, Sri Lance i Nepalu oraz w Ameryce Południowej - szczególnie w Brazylii. Państwa te (poza Nepalem) są określane przez ONZ (na podstawie wartości tzw. Wskaźnika Rozwoju Społecznego) jako wysoko lub średnio rozwinięte. Rozprzestrzenianiu się trądu sprzyja tam rozwój dużych ośrodków miejskich, do których napływa uboga ludność poszukująca poprawy swojej sytuacji 
materialnej. W efekcie powstają całe dzielnice tzw. slumsów, gdzie panują bardzo trudne warunki higieniczne i sanitarne. Brak tam najczęściej kanalizacji, wodociągów, systemów odbioru odpadów, a dostęp do opieki medycznej jest znacząco ograniczony.

Drugą grupą krajów, gdzie problem trądu jest wciąż aktualny, są skrajnie ubogie obszary w krajach afrykańskich (zaliczanych przez ONZ do państw słabo rozwiniętych). W efekcie w Nigerii, Tanzanii, Etiopii, Sudanie Południowym czy Demokratycznej Republice Konga liczba zachorowań jest nadal wysoka (ryc. 1). Fatalny stan służby zdrowia sprawia, że chorzy mają bardzo utrudniony dostęp do leczenia. Standardy higieniczne panujące w tych krajach, a także poziom edukacji związanej z ochroną zdrowia są również bardzo niskie.

Przytoczone statystyki jasno pokazują, że trąd nie zniknął całkowicie ze świata i mimo stosowania skutecznych metod leczenia wciąż wiele osób doświadcza związanego z nim bólu fizycznego, a często również i odrzucenia (por. Rafferty 120-121). Na szczęście jednak poziom opieki nad chorymi znacząco się poprawił. Obecnie posługą wśród trędowatych zajmuje się wielu oddanych sprawie misjonarzy i wolontariuszy, dzięki czemu mają oni szanse na powrót do zdrowia i życia w społeczeństwie. O chorobie przypomina również Światowy Dzień Chorych na Trąd, który obchodzony jest w ostatnią niedzielę stycznia.

\section{Podsumowanie}

W artykule starano się kompleksowo podejść do analizy zagadnień związanych z trądem. Pozwala to spojrzeć na problem z różnych perspektyw. Analiza aspektów medycznych daje pewne wyobrażenie o możliwych kierunkach rozwoju choroby i jej konsekwencjach dla osób zakażonych. Pozwala również łatwiej zrozumieć, dlaczego choroba w przeszłości była źródłem tak ogromnych cierpien fizycznych i psychicznych dla osób nią dotkniętych. Podobną rolę odgrywa analiza tekstów biblijnych. Dzięki temu został zarysowany pewien kontekst dla dalszych rozważań na temat historii rozwoju trądu na świecie, który pozwala również ukazać kształtujące się na przestrzeni dziejów podejście społeczne do choroby i osób nią zarażonych. W przeszłości nie znano lekarstwa na trąd. W efekcie niemal zawsze choroba ta prowadziła do długotrwałych cierpień i w końcu do śmierci. Dużo wcześniej następowała zwykle „śmierć społeczna" osoby nią dotkniętej. Odrażający wygląd i zapach chorego, a także strach przed zakażeniem sprawiały, że chorych izolowano. Często też łączono trąd z karą za popełnione grzechy. W efekcie osoby chore poza bólem fizycznym doświadczały również wielu szykan i umierały w samotności. 


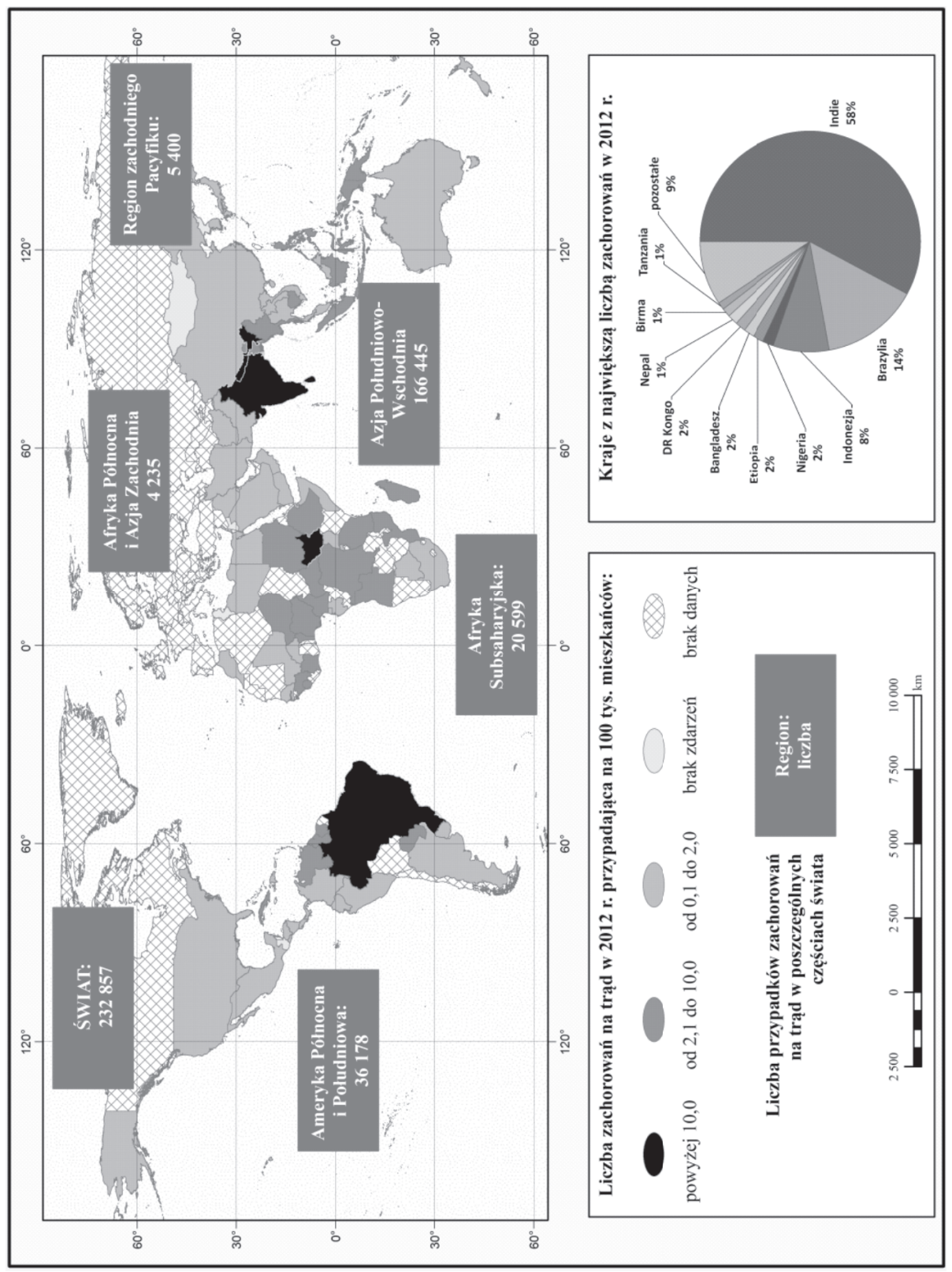

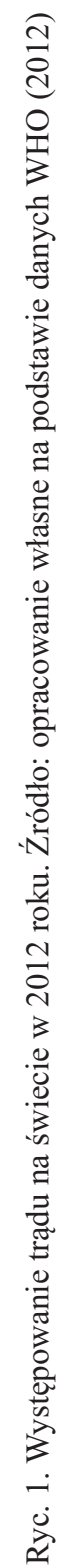


Znalazły się jednak jednostki, które wzorując się na postawie Jezusa, nie odtrąciły trędowatych, a wręcz poświęciły swoje życie, służąc im i pomagając w cierpieniu. Wydaje się, że właśnie zestawienie różnych postaw ludzkich wobec osób zakażonych tą chorobą pozwala prawdziwie docenić działalność takich postaci, jak bł. Jan Beyzym, bł. Damian de Vuster czy bardziej nam współcześni bł. Matka Teresa z Kalkuty, o. Marian Żelazek czy dr Wanda Błeńska. Dzięki nim choroba ta stała się bardziej „ludzka”, a cierpiące na nią osoby zaczęły wreszcie doświadczać współczucia, pociechy i wsparcia.

\title{
LEPROSY AND THE HISTORY OF ITS PERCEPTION
}

\begin{abstract}
ABS T R ACT
The article focuses on leprosy and the history of its perception. Authors tried to present complexity of the analysed problem and consider its different aspects (medical, psychological and spiritual consequences). In the first part they describe the origins and effects of this disease from the medical point of view and subsequently offer a short history of leprosy. It starts with the descriptions from the Holy Bible (both Old and New Testament). Then, the situation in the Middle Ages and later centuries is considered. One section is also dedicated to individuals who devoted their lives to help people with leprosy. All these fragments of the article show a plight of leprosyaffected persons who always suffered from physical pain and social rejection. In the final section of the article the authors describe current situation of leprosy in the world. Cited statistics confirm that leprosy is still a problem in some parts of our globe, primarily in developing countries, where it still causes a lot of suffering. Therefore, we should conclude that leprosy remains a valid issue even in 21 st century.
\end{abstract}

Keywords: leprosy; Hansen's disease; leprosarium; social rejection

Slowa kluczowe: trąd; choroba Hansena; leprozorium; wykluczenie społeczne

\section{BIBLIOGRAFIA}

Andrzejak, Ambroży. „Trąd wczoraj i dziś.” Misyjne Drogi 4 (1983): 31-32.

Augustynowicz-Kopeć, Ewa. Zwolska, Zofia. „Wybrane zagadnienia biologii Mycobacterium leprae.” Postepy Nauk Medycznych (2011) nr 10. (opublikowano 30 kwietnia 2015). <http:// www.czytelniamedyczna.pl/3794,wybrane-zagadnienia-biologii-mycobacterium-leprae.html> Błeńska, Wanda. „Trąd.” Medicus Mundi Poland, 2 (2002) nr 6-7: 5-8.

Brakel, van, Wim H. "Measuring leprosy stigma-a preliminary review of the leprosy literature." International Journal of Leprosy and Other Mycobacterial Diseases 71.3 (2003): 190-197. 
Browne, Stanley G. Some aspects of the history of leprosy: the leprosie of yesterday. "Proceedings of the Royal Society of Medicine" 68.8 (1975): 485-493.

Emond, Ronald Temple Duncan. Rowland, Herbert Albert Kenneth. Welsby, Philip Douglas. Atlas chorób zakaźnych. Tłum. Janusz Cianciara. Warszawa: Springer PWN, 1996.

Ferenc, Ewelina. „Czym jest trąd?” Wanda Błeńska. Spetnione życie. Red. Joanna Molewska, Marta Pawelec. Poznań: Św. Wojciech, 2011. 230-234.

Florek-Mostowska, Monika. „Trąd w Europie? Wywiad przeprowadzony z prof. Anną Doboszyńską." Idziemy 7 (2011). (opublikowano 1 maja 2015). <http://www.opoka.org.pl/biblioteka/P/ PS/idziemy201107_trad.html\#>

Gądecki, Stanisław. Homilia Arcybiskupa Poznańskiego. Światowy Dzień Chorego 12.2.2012. (opublikowano 17 sierpnia 2015). <http://www.archpoznan.pl/content/view/2288/109/>

Janaszek, Wiesława. „Perspektywa eliminacji trądu w świecie. Szczepienia ochronne a leczenie etiotropowe.” Przeglad Epidemiologiczny 56.4 (2002): 577-586.

Kocięcka, Wanda. „Współczesne zagadnienia z zakresu epidemiologii i patologii klinicznej trądu.” Wiadomości Parazytologiczne 41.4 (1995): 373-390.

Kocięcka, Wanda. „Współczesne zagadnienia z zakresu epidemiologii i patologii klinicznej trądu.” Wanda Bteńska-Doctor honoris causa Akademii Medycznej im. Karola Marcinkowskiego. Poznań: AM im. K. Marcinkowskiego, 1994. 57-75.

Krzyżostaniak, Hanna. „Miłosierdzie w legendzie Św. Agnieszki Czeskiej - przyczynek do dziejów duchowości franciszkańskiej." Miłosierdzie. Teoria i praktyka życiowa. Red. Paweł Nowakowski, Wiktor Szymborski. Kraków: Księgarnia Akademicka, 2009. 43-54.

Łęczycka, Agata. „Świadomość serca. Dzień pomocy chorym na trąd - 30 stycznia.” Niedziela (2011) nr 5: 22.

Matwiejczuk, Paweł. „Trąd - wielkie oczy strachu.” Mówia wieki (2009) nr 2.589. (opublikowano 30 kwietnia 2015). <http://www.mowiawieki.pl/index.php?page=artykul\&id=117>

Molewska, Joanna. Pawelec, Marta. Wanda Błeńska. Spetnione życie. Poznań: Św. Wojciech, 2011.

Muth-Oelschner, Brigitte. Gdzie miłość leczyła trąd. Damian de Veuster. [Misjonarze, którzy tworzyli historie]. Warszawa: Verbinum, 1990.

Nawrocka, Małgorzata. Jej światło. O życiu i dziele Wandy Błeńskiej. Poznań: Kontekst, 2005.

Nowak, Krystyna. Suryło, Piotr. „Nowe leki przeciwtrądowe.” Wiadomości Chemiczne 62.5-6 (2008): 513-531.

Rafferty, Joy. "Curing the stigma of leprosy." Leprosy review 76.2 (2005): 119-126.

Sermak, Jerzy. „Nawet trąd może być uleczony. Wywiad z dr Barbarą Stryjewską.” Posłaniec Serca Jezusowego (2004). (opublikowano 30 kwietnia 2015). <http://www.psj.net.pl/?0404,artyku1,nawet_trad>

Spink, Kathryn. Matka Teresa. Autoryzowana biografia. Lublin: Wydawnictwo Gaudium, 2001.

Supady, Jerzy J. „Przykłady ewolucji zjawiska śmierci z powodu chorób zakaźnych w aspekcie historycznym.” Studia Medyczne 13 (2009): 79-84.

Szałata, Urszula. „Ta choroba ma 4 tysiące lat”. Niedziela (2012) nr 5. (opublikowano 2 maja 2015). $<$ http://www.niedziela.pl/artykul/96989/nd/Ta-choroba-ma-4-tysiace-lat>

Trautman, John R. "A brief history of Hansen's disease." Bulletin of the New York Academy of Medicine 60.7 (1984): 689-695.

Wojtczak, Jerzy A. Średniowieczne życiorysy bt. Kingi i bł. Salomei. Warszawa: UW, 1999.

World Health Organization. "Global leprosy: update on the 2012 situation." Weekly Epidemiological Record 88.35 (2013): 365-378. (opublikowano 17 sierpnia 2015). <http://www.who.int/ wer/2013/wer8835.pdf?ua=1>

MARTA JeloneK - Tytuł magistra pedagogiki specjalnej uzyskała na Wydziale Studiów Edukacyjnych Uniwersytetu im. Adama Mickiewicza w Poznaniu. Pracuje z dziećmi niepełnosprawnymi w integracyjnej grupie przedszkolnej. W la- 
tach 2008-2013 członkini Akademickiego Koła Misjologicznego działającego przy Wydziale Teologicznym UAM w Poznaniu. Współautorka książki „Wanda Błeńska. Spełnione życie” (Wydawnictwo Święty Wojciech, Poznań, 2011).

JoAnNa GAdzińSKA - Tytuł magistra biologii uzyskała na Wydziale Biologii Uniwersytetu im. Adama Mickiewicza w Poznaniu. Od 2013 r. pracuje W Ogrodzie Botanicznym UAM. Zajmuje się edukacją przyrodniczą. W latach 2007-2012 członkini Akademickiego Koła Misjologicznego działającego przy Wydziale Teologicznym UAM w Poznaniu. Współautorka książki „Wanda Błeńska. Spełnione życie (Wydawnictwo Święty Wojciech, Poznań, 2011)

JęDRZEJ GADZIŃSKI - Adiunkt w Instytucie Geografii Społeczno-Ekonomicznej i Gospodarki Przestrzennej na Uniwersytecie im. Adama Mickiewicza w Poznaniu. Specjalizuje się w badaniach współczesnych przemian przestrzeni miast i regionów, a także w analizach kartograficznych (GIS). W latach 2007-2013 członek Akademickiego Koła Misjologicznego działającego przy Wydziale Teologicznym UAM w Poznaniu. 